\title{
Effect of Obidoxime Therapy on Cholinesterase Enzymes' Reactivation in Clinically Diagnosed Patients With Acute Organophosphate Toxicity
}

\author{
Alyaa A. A.Othman ${ }^{1}$, Hend M. H. Abo El-Atta ${ }^{1}$, Seham Aly Gad-ElHak ${ }^{1}$, Abdel-Aziz A.Ghanem ${ }^{1}$
}

\begin{abstract}
KEYWORDS

Acetylcholinesterase (ACHE), Butyrylcholinesterase (BuCHE), Organophosphate,

Obidoxime,

Intermediate syndrome.

Organophosphorus poisoning has significant clinical importance, especially in the developing countries, due to its major health consequences. The study evaluated role of obidoxime in reactivation of cholinesterase (ACHE, BuCHE) enzymes in acute organophosphorus (OP) intoxicated patients. It was conducted on group I: 50 patients received obidoxime therapy after acute OP intoxication, and group II: 50 patients did not receive obidoxime. Patients were subjected to neurological evaluation, determination of $\mathrm{ACHE}$ and BuCHE levels. Results revealed that there were statistically significant differences between both groups regarding clinical outcomes, with variability of significance regarding initial and final levels of cholinesterase enzymes. It was concluded that BuCHE enzymes' levels can be considered sensitive biomarker for OP exposure and severity, while, ACHE activity reflected the recovery.
\end{abstract}

\section{Introduction}

Organophosphorus (OP) pesticides' intoxication is a public human health issue due to their worldwide use for pest control and documented human exposure, causing huge number of poisonings, primarily in developing countries (Alfonso et al., 2017). One of the major neurological sequelae of organophosphorus poisoning is intermediate syndrome (IMS) which might go unnoticed if the clinician has not included it in the differential diagnosis. Although it is reversible in most cases, some patients might develop features of respiratory muscle weakness,

\footnotetext{
${ }^{(1)}$ Forensic Medicine and Clinical Toxicology Department, Faculty of Medicine, Mansoura University, Egypt.
}

progressing into respiratory failure (Sarkar et al., 2014).

Oximes (obidoxime) are considered a standard line of management for acute organophosphorus poisoning; however, its exact role in prevention of IMS is still a matter of debate (Eddleston, 2018). Some clinicians suggested that IMS may result from inadequate oxime therapy (Thiermann et al., 2010; Abedin et al., 2012). Others stated that oximes are not necessary and their role in IMS prevention is questioned (Malkarnekar et al., 2014; Eddleston and Chowdhury, 2016). The present study aims to evaluate the role of obidoxime therapy in the reactivation of cholinesterase (acetylcholinesterase, ACHE and butyrylcholinesterase, BuCHE) enzymes in patients with acute organophosphorus intoxication. 


\section{Subjects and Methods}

A cohort study was conducted on patients with acute OP toxicity recruited from Mansoura University Emergency Hospital and Damietta General Hospital over a period of three years; from the end of September, 2014 till the end of September, 2017.

\subsection{Subjects:}

One hundred patients whom were clinically diagnosed with OP toxicity, adults of both sexes aged from 18 to 60 years, were included in the study. Exclusion criteria: anemia, chronic debilitating diseases as cancer, liver diseases, diabetes mellitus and neurological disorders, alcohol consumption, pregnancy and patients presented to hospital after 12 hours of the onset of manifestations or previously treated in another hospital to manage toxicity; all were excluded from the study.

Study design: all patients received standardized OP toxicity line of therapy according to WHO (2014), they were divided into two groups:

Group I: fifty patients recruited from Mansoura University Emergency Hospital, received obidoxime therapy after acute OP intoxication in a bolus dose of $250 \mathrm{mg}$ followed by infusion of $750 \mathrm{mg}$ every 24 hours till clinical stabilization of the patient (WHO, 2014). Then, they were subdivided into: Group Ia: all patients were investigated immediately after admission before administration of medications. Group $\boldsymbol{I} \boldsymbol{b}$ : the same group (Ia) but, they were investigated after clinical stabilization "24 hours after stoppage of obidoxime therapy".

Group II: fifty patients recruited from Damietta General Hospital and did not receive obidoxime therapy, they were subdivided into: Group $\Pi$ a: patients were investigated immediately after admission before administration of medications. Group $\boldsymbol{\Pi b}$ : the same group (IIa) but, they were investigated after clinical stabilization.

All patients participated in the current study signed informed consent forms. The study protocol was approved by the Institutional Review Board of Faculty of Medicine, Mansoura University (code number: 123).

2.2 Each patient from group I and group II was subjected to the following:

(I)Clinical evaluation includes the following:

a- General and systemic examination to exclude non-convenient patients.

$\boldsymbol{b}$ - Neurological examination was done including: Glasgow coma scale, motor system examination (Tawa et al., 2017): that included: muscle fasciculations (absent, generalized or continuous, generalized and continuous); assessment of muscle tone (normal, hypotonia, hypertonia); muscle power (intact, weakness, paralysis); and deep tendon reflexes (normal, hyporeflexia, hyperreflexia, areflexia). As well, assessment of intermediate syndrome was done after $24 \mathrm{hrs}$. according to Khan et al. (2012).

c- Clinical severity scoring was assessed according to Peradeniya Organophosphorus Poisoning (POP) scale to divide patients accordingly into mild, moderate, severe grades (Kumar et al., 2015).

\subsection{Methods:}

\subsubsection{Material:}

Acetylthiocholine iodide, malathion (98\%), palladium chloride, Sbutyrylthiocholine iodide (BTC), sodium carbonate monohydrate $(\mathrm{NaH} 2 \mathrm{CO} 4)$, sodium dihydrogen phosphate (NaH2PO4), sodium phosphate buffer (P.B.) (NaHPO4), 5, 5'dithiobis (2-nitrobenzoic acid) (DTNB); were purchased from MERK Company. Other 
chemicals such as N-Hexane, hydrochloric acid, sodium hydrogen phosphate (Na2HPO4), sulphuric acid were purchased from $\mathrm{BDH}$ Company, and BuCHE assay kit from BioVision Company.

\subsubsection{Methods:}

\section{a- Sampling:}

From each patient, ten $\mathrm{ml}$ of blood was taken immediately after admission before administration of any medications. It was divided into two parts: five $\mathrm{ml}$ was kept without preservatives for estimation of BuCHE enzyme levels and the other half was heparinized for estimation of ACHE enzyme activities. Another ten $\mathrm{ml}$ of blood was taken after clinical stabilization of the patient $(24 \mathrm{hs}$ after stoppage of obidoxime therapy) for reestimation of cholinesterase's enzyme levels and activities. They were divided similarly to the previous blood sample

\section{$b$ - Measurement of acetylcholinesterase enzyme activity and butyrylcholinesterase} enzyme levels:

The ACHE enzyme activity was measured according to Ellman's method using acetylthiocholine as substrate at reference value $(10.2 \mu$ moles $/ \mathrm{min} / \mathrm{ml}$ red cells) (Worek et al., 2012). Meanwhile, butyrylcholinestrase enzyme levels were determined according to the modified Ellman's method using Sbutyrylthiocholine iodide as a substrate at a reference value (3000-9000 IU) (Jońca et al., 2015); using the microlab auto-analyzer.

\section{Statistical analysis}

Data analysis was performed using the $19^{\text {th }}$ version of SPSS (Statistical Package for Social Sciences/Inc., Chicago, IL, USA). Qualitative data is presented in form of frequencies (number and percent); while quantitative data is presented in mean \pm standard deviation (S.D). The normality of data distribution was tested to decide whether parametric or non-parametric data using Kolmogorov-Smirnov test. The mean values between the two studied groups were compared using the student T-test while ANOVA, Fisher Exact, Mont Carlo Exact Probability tests were used to compare the mean values between the control and the studied groups. The significance level was kept at the level of less than $0.05(\mathrm{p}<0.05)$.

\section{Results}

Both study groups were age and sex matched, the age of the patients ranged from 18 to 59 years in group I and 19 to 59 years in group II. Regarding sociodemographic and clinical data of organophosphorus intoxicated patients, no statistically significant differences between the studied groups (data not shown).

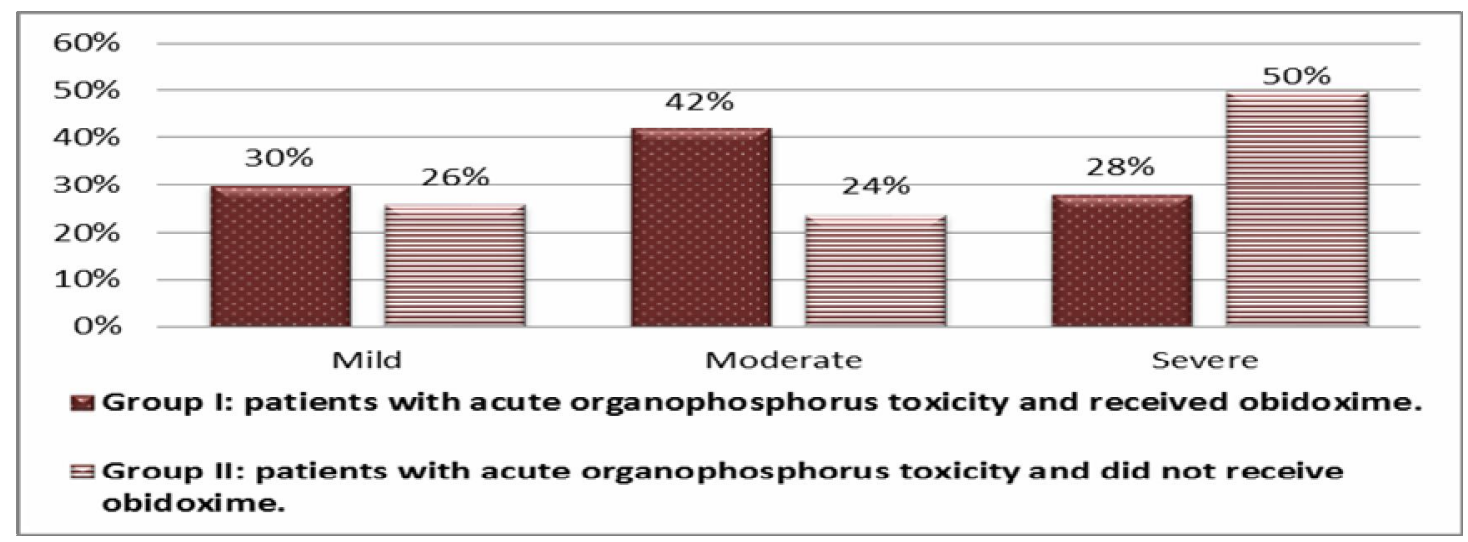

Fig. (1): Distribution of the studied patients according to Peradeniya Organophosphorus Poisoning (POP) scale ( $\mathrm{n}=100)$. 
Tables (1) \& (2) demonstrate the association between clinical severities using POP scale among patients of both groups as regard ACHE enzyme's activities, BuCHE enzyme's levels, atropine requirements, duration of hospital stay, ventilatory support and clinical outcomes in both study groups respectively. Table (3) shows comparison of each grade of POP scale between group I and group II for the same parmeters.

Table (1): Association between clinical severity using Peradeniya Organophosphorus Poisoning (POP) scale and cholinesterase enzymes' levels, atropine requirements during illness, duration of hospital stay, need for mechanical ventilation and clinical outcomes among patients of Mansoura University Emergency Hospital $(\mathrm{n}=50)$.

\begin{tabular}{|c|c|c|c|c|}
\hline \multirow{2}{*}{ Parameters } & \multicolumn{4}{|c|}{ Group I $(n=50)$} \\
\hline & Mild (n=15) & Moderate $(n=21)$ & Severe $(n=14)$ & p-value \\
\hline $\begin{array}{l}\text { ACHE enzyme's levels } \\
(\mu \text { moles } / \mathrm{min} . / \mathrm{ml} \text { red cells }) \\
\text { mean } \pm \text { S.D } \\
\text { Group Ia } \\
\text { Group Ib }\end{array}$ & $\begin{array}{c}6.3 \pm 1.95 \\
7.75 \pm 1.47\end{array}$ & $\begin{array}{l}5.56 \pm 1.91 \\
7.17 \pm 1.73\end{array}$ & $\begin{array}{l}4.98 \pm 2.013 \\
6.235 \pm 1.765\end{array}$ & $\begin{array}{r}0.075 \\
0.029 *\end{array}$ \\
\hline $\begin{array}{l}\text { BuCHE enzyme's levels (IU) } \\
\text { mean } \pm \text { S.D } \\
\text { Group Ia } \\
\text { Group Ib }\end{array}$ & $\begin{array}{c}2181.94 \pm 191.26 \\
3646.63 \pm 159.1\end{array}$ & $\begin{array}{l}1822.71 \pm 186.89 \\
3466.47 \pm 199.95\end{array}$ & $\begin{array}{l}886.62 \pm 96.174 \\
2011.8 \pm 171.93\end{array}$ & $\begin{array}{l}0.045^{*} \\
0.022^{*}\end{array}$ \\
\hline $\begin{array}{l}\text { Atropine requirement }(\mathrm{mg}) \\
\text { mean } \pm \text { S.D } \\
\text { Initial } 24 \text { hrs. dose } \\
\text { Total illness dose }\end{array}$ & $\begin{array}{l}40 \pm 7.51 \\
73 \pm 8.19\end{array}$ & $\begin{array}{c}75 \pm 9.25 \\
110 \pm 9.87 \\
\end{array}$ & $\begin{array}{c}88 \pm 8.33 \\
160 \pm 9.88 \\
\end{array}$ & $\begin{array}{l}0.02 * \\
0.01 *\end{array}$ \\
\hline $\begin{array}{l}\text { Duration of hospital stay } \mathbf{n} .(\%) \\
\text { Up to } 48 \mathrm{hrs} \text {. } \\
48-72 \mathrm{hrs} . \\
>72 \mathrm{hrs} .\end{array}$ & $\begin{array}{c}0 \\
10(67 \%) \\
5(33 \%)\end{array}$ & $\begin{array}{c}0 \\
11(52 \%) \\
10(48 \%)\end{array}$ & $\begin{array}{c}0 \\
1(\% 7) \\
13(93 \%)\end{array}$ & $0.001 *$ \\
\hline Ventilatory support $\quad$ n.(\%) & $1(7 \%)$ & $4(19 \%)$ & $12(86 \%)$ & $0.000 *$ \\
\hline $\begin{array}{l}\text { Clinical outcomes } \\
\text { Clinical improvement } \\
\text { Intermediate syndrome } \\
\text { Death }\end{array}$ & $\begin{array}{c}15(100 \%) \\
0 \\
0\end{array}$ & $\begin{array}{c}21(100 \%) \\
0 \\
0\end{array}$ & $\begin{array}{c}0 \\
13(93 \%) \\
1(7 \%)\end{array}$ & $0.000^{*}$ \\
\hline
\end{tabular}

*p-value $\leq 0.05$ is significant. S.D: standard deviation. ACHE: acetylcholinesterase. BuCHE: butyrylcholinesterase. n: number. hrs.: hours. $\boldsymbol{\mu}$ moles: micro moles. min.: minute. ml: milliliter. IU: international unit. mg: milligram.

Group I: patients with acute organophosphorus toxicity and received obidoxime.

Group Ia: refers to the initial level on admission of patients in group I.

Group Ib: refers to the final level after clinical stabilization of patients in group I. 
Table (2): Association between clinical severity using Peradeniya Organophosphorus Poisoning (POP) scale and cholinesterase enzymes' levels, atropine requirements during illness, duration of hospital stay, need for mechanical ventilation and clinical outcomes among patients of Damietta General Hospital $(n=50)$.

\begin{tabular}{|c|c|c|c|c|}
\hline \multirow{2}{*}{ Parameters } & \multicolumn{4}{|c|}{ Group II } \\
\hline & Mild (n=13) & Moderate $(n=12)$ & Severe $(n=25)$ & p-value \\
\hline $\begin{array}{l}\text { ACHE enzyme's levels } \\
(\mu \text { moles } / \mathrm{min} / \mathrm{ml} \text { red cells }) \text { mean } \pm \text { S.D } \\
\text { Group II a } \\
\text { Group II b }\end{array}$ & $\begin{array}{l}4.5 \pm 1.847 \\
8.58 \pm 0.74 \\
\end{array}$ & $\begin{array}{c}3.89 \pm 1.567 \\
8.325 \pm 1.743 \\
\end{array}$ & $\begin{array}{l}3.105 \pm 1.767 \\
7.112 \pm 2.279 \\
\end{array}$ & $\begin{array}{c}0.02 * \\
0.019 *\end{array}$ \\
\hline $\begin{array}{l}\text { BuCHE enzyme's levels (IU) } \\
\text { mean } \pm \text { S.D } \\
\text { Group II a } \\
\text { Group II b } \\
\end{array}$ & $\begin{array}{c}1415.38 \pm 51.887 \\
3245.5 \pm 60.51 \\
\end{array}$ & $\begin{array}{c}1015.916 \pm 139.26 \\
3028 \pm 340.14 \\
\end{array}$ & $\begin{array}{l}1030.52 \pm 258.32 \\
3101.45 \pm 294.16 \\
\end{array}$ & $\begin{array}{l}0.514 \\
0.576 \\
\end{array}$ \\
\hline $\begin{array}{l}\text { Atropine requirements (mg) } \\
\text { mean } \pm \text { S.D } \\
\text { Initial } 24 \text { hrs. dose } \\
\text { Total illness dose } \\
\end{array}$ & $\begin{array}{l}35 \pm 5.71 \\
68 \pm 6.64 \\
\end{array}$ & $\begin{array}{l}44 \pm 7.15 \\
80 \pm 8.13 \\
\end{array}$ & $\begin{array}{c}80 \pm 8.13 \\
150 \pm 10.01 \\
\end{array}$ & $\begin{array}{c}0.04^{*} \\
0.019^{*} \\
\end{array}$ \\
\hline $\begin{array}{l}\text { Duration of hospital stay n. (\%) } \\
\text { Up to } 48 \mathrm{hrs} . \\
48-72 \mathrm{hrs} . \\
>72 \mathrm{hrs} \text {. }\end{array}$ & $\begin{array}{c}1(7 \%) \\
3(23 \%) \\
9(70 \%) \\
\end{array}$ & $\begin{array}{c}0 \\
4(33 \%) \\
8(67 \%) \\
\end{array}$ & $\begin{array}{c}0 \\
1(4 \%) \\
24(96 \%) \\
\end{array}$ & $0.017 *$ \\
\hline Ventilatory support n. (\%) & 0 & $1(8 \%)$ & $20(80 \%)$ & $0.000 *$ \\
\hline $\begin{array}{l}\text { Clinical outcomes n. (\%) } \\
\text { Clinical improvement } \\
\text { Intermediate syndrome } \\
\text { Death }\end{array}$ & $\begin{array}{c}13(100 \%) \\
0 \\
0\end{array}$ & $\begin{array}{c}12(100 \%) \\
0 \\
0\end{array}$ & $\begin{array}{c}0 \\
19(76 \%) \\
6(24 \%)\end{array}$ & $0.000^{*}$ \\
\hline
\end{tabular}

*p-value $\leq \mathbf{0 . 0 5}$ is significant. S.D: standard deviation. ACHE: acetylcholinesterase. BuCHE: butyrylcholinesterase. n: number. hrs.: hours. $\boldsymbol{\mu}$ moles: micro moles. min.: minute. ml: milliliter. IU: international unit. mg: milligram.

Group II: patients with acute organophosphorus toxicity and did not receive obidoxime.

Group IIa: refers to the initial level on admission of patients in group II.

Group IIb: refers to the final level after clinical stabilization of patients in group II. 
Table (3): Comparison of each grade of Peradeniya Organophosphorus Poisoning (POP) scale between both patients' groups $(\mathrm{n}=100)$.

\begin{tabular}{|l|c|c|c|c|c|c|}
\hline \multirow{2}{*}{ Parameters } & \multicolumn{2}{c|}{ Mild grade\# } & \multicolumn{2}{c|}{ Moderate grade\# } & \multicolumn{2}{c|}{ Severe grade\# } \\
\cline { 2 - 7 } & t-value & p-value & t-value & p-value & t-value & $\begin{array}{c}\text { p- } \\
\text { value }\end{array}$ \\
\hline $\begin{array}{l}\text { ACHE enzyme's levels ( } \mu \\
\text { moles/min/ ml red cells) }\end{array}$ & & & & & \\
Group a & 2.851 & $0.008^{*}$ & 2.557 & 0.16 & 2.951 & $0.006^{*}$ \\
Group b & 1.972 & 0.06 & 1.837 & 0.076 & 1.102 & 0.278 \\
\hline BuCHE enzyme's levels (IU) & & & & & & \\
Group a & 1.229 & 0.23 & 1.463 & 0.153 & 0.318 & 0.753 \\
Group b & 1.201 & 0.241 & 0.606 & 0.549 & 2.546 & $0.015^{*}$ \\
\hline Atropine requirements (mg) & & & & & & \\
Initial 24 hrs. dose & 1.233 & 0.244 & 1.45 & 0.23 & 1.356 & 0.311 \\
Total illness dose & 1.213 & 0.21 & 1.234 & 0.63 & 1.222 & 0.230 \\
\hline Duration of hospital stay & 2.044 & 0.051 & 1.042 & 0.31 & 0.716 & 0.478 \\
\hline Ventilatory support & 1.927 & 0.07 & 0.49 & 0.627 & 0.215 & 0.831 \\
\hline Clinical Outcomes & legend & & 1 legend & & 1.222 & 0.230 \\
\hline
\end{tabular}

*p-value $\leq \mathbf{0 . 0 5}$ is significant. ACHE: acetylcholinesterase. BuCHE: butyrylcholinesterase. hrs.: hours. $\boldsymbol{\mu}$ moles: micro moles. min.: minute. n: number. ml: milliliter. IU: international unit. mg: milligram. \#: group I versus group II.

Group I: patients with acute organophosphorus toxicity and received obidoxime.

Group П: patients with acute organophosphorus toxicity and did not receive obidoxime.

Group a: refers to the initial level on admission.

Group b: refers to the final level after clinical stabilization.

Legend: all cases in this group show clinical improvement hence standard deviation $=0$ and no comparison can be computed.

Table (4) demonstrates the clinical outcomes among both studied groups. It is shown that a statistically significant improvement was observed regarding the clinical improvement between both studied groups; meanwhile no statistically significant differences were observed regarding the prevention of IMS or death between both groups.

Table (4): Comparisons between patients' groups regarding their clinical outcomes $(n=100)$.

\begin{tabular}{|c|c|c|c|c|c|c|c|c|c|}
\hline \multirow{3}{*}{$\begin{array}{c}\text { Clinical outcomes } \\
\text { Clinical improvement }\end{array}$} & \multicolumn{2}{|c|}{$\begin{array}{c}\text { Group I } \\
(n=50)\end{array}$} & \multicolumn{2}{|c|}{$\begin{array}{c}\text { Group II } \\
(\mathrm{n}=50)\end{array}$} & \multicolumn{2}{|c|}{$\begin{array}{c}\text { Total } \\
(\mathrm{n}=\mathbf{1 0 0})\end{array}$} & \multirow{2}{*}{$\begin{array}{c}\text { Significance } \\
\text { test }\end{array}$} & \multirow{2}{*}{\multicolumn{2}{|c|}{ p-value }} \\
\hline & n. & $\%$ & n. & $\%$ & n. & $\%$ & & & \\
\hline & 36 & 72.0 & 25 & 50.0 & 61 & 61 & $\chi^{2}=5.090$ & $0.024 *$ & \multirow{3}{*}{$\begin{array}{l}\mathrm{MEP}^{¥} \\
0.0431\end{array}$} \\
\hline Intermediate syndrome & 13 & 26.0 & 19 & 38.0 & 32 & 32 & $\chi^{2}=1.650$ & 0.198 & \\
\hline Death & 1 & 2.0 & 6 & 12.0 & 7 & 7 & FET $^{\neq}$ & 0.055 & \\
\hline
\end{tabular}

*p-value $\leq \mathbf{0 . 0 5}$ is significant. $\neq \mathbf{F E T}$ : Fisher Exact test. ${ }^{\mathrm{y}}$ MEP: Mont Carlo Exact Probability. $\mathbf{n}$ : number.

Group I: patients with acute organophosphorus toxicity and received obidoxime.

Group II: patients with acute organophosphorus toxicity and did not receive obidoxime. 
Estimation of cholinesterase (red cell ACHE and serum BuCHE) enzymes' levels was done for all patients twice (on admission and after clinical stabilization). ANOVA test shows statistically significant differences among the studied groups regarding the cholinesterase enzymes' levels $(p=0.000)$ (Table 5).

Table (5): Comparisons of acetylcholinesterase and butyrylcholinesterase enzymes' levels between the studied groups $(\mathrm{n}=100)$.

\begin{tabular}{|c|c|c|c|c|}
\hline & & $\begin{array}{c}\text { Group I } \\
(\mathbf{n}=\mathbf{5 0})\end{array}$ & $\begin{array}{c}\text { Group II } \\
(\mathrm{n}=\mathbf{5 0})\end{array}$ & p-value \\
\hline \multirow{2}{*}{$\begin{array}{c}\text { ACHE enzyme's levels } \\
(\mu \text { moles } / \mathrm{min} / \mathrm{ml} \text { red cells }) \\
\text { mean } \pm \text { S.D }\end{array}$} & Group a & $5.61 \pm 1.97$ & $3.66 \pm 1.81$ & $0.000^{*}$ \\
\hline & Group b & $8.1 \pm 1.73$ & $7.79 \pm 1.9$ & 0.067 \\
\hline \multicolumn{2}{|l|}{$\begin{array}{r}\text { ANOVA } \\
\end{array}$} & \multicolumn{3}{|c|}{$0.000^{*}$} \\
\hline \multirow{2}{*}{$\begin{array}{c}\text { BuCHE enzyme's levels } \\
\text { (IU) } \\
\text { mean } \pm \text { S.D } \\
\end{array}$} & Group a & $1668.4 \pm 172.79$ & $1127.1 \pm 64.86$ & $0.036^{*}$ \\
\hline & Group b & $3913.2 \pm 190.43$ & $2101.45 \pm 99.41$ & 1.000 \\
\hline \multicolumn{2}{|l|}{$\begin{array}{r}\text { ANOVA } \\
\end{array}$} & \multicolumn{3}{|c|}{$0.000 *$} \\
\hline
\end{tabular}

*p-value $\leq \mathbf{0 . 0 5}$ significant. S.D: standard deviation. ACHE: acetylcholinesterase. BuCHE: butyrylcholinesterase. $\boldsymbol{\mu}$ moles: micro moles. min.: minute. $\mathbf{n}$ : number. ml: milliliter. IU: international unit. ACHE: acetylcholinesterase. BuCHE: butyrylcholinesterase.

Group I: patients with acute organophosphorus toxicity and received obidoxime.

Group II: patients with acute organophosphorus toxicity and did not receive obidoxime.

Group a: refers to the initial levels on admission.

Group b: refers to the final levels after clinical stabilization.

\section{Discussion}

Organophosphorus poisoning is an important clinical health problem in the developing countries due to easy availability and accessibility. Neurological complications following acute OP exposure represent a major health issue, especially IMS which is considered a life threatening condition (Eddleston, 2018). The present study aimed to determine the effectiveness of obidoxime therapy in reactivation of cholinesterase enzymes among patients with acute OP toxicity from Mansoura and Damietta cities.

In the present study, the wide range of ages can be explained by wide distribution of OP compounds use in Egypt and high incidence of early OP exposure among youth; either occupationally or through para suicide. This is in accordance with the findings of
Makwava et al. (2012) who reported that ages of their studied patients ranged from 15 years to 65 years.

In group I, the initial levels of ACHE enzyme didn't show any significant differences among the three sub-groups, suggesting that initial ACHE enzymes' levels are not specific indicators of the clinical severity. These results are supported by Osman (2011) who stated that, the preliminary ACHE enzymes' levels are generally low in chronically exposed individuals who live adjacent to regularly sprayed agricultural fields. However, the results were inconsistent with the established fact that ACHE enzyme's activity of less than $10 \%$ would clinically indicate severe poisoning, while 10$30 \%$ activity is associated with moderate poisoning, and ACHE enzyme's activity greater than $30 \%$ is associated with mild degree of poisoning (Eddleston et al., 2008). This can be 
explained by the role of other non-ACHE enzymes inhibited by OPs and the actual use of mixed formulation of pesticides (Eddleston et al., 2012). Roberts and Brett (2014) reported that, symptoms are not always present in ACHE enzyme-depressed individuals; and there are differences between all OPCs regarding ACHE enzyme's inhibition. Furthermore, there are baseline variations of ACHE enzyme's activity among individuals, as it may be suppressed in exposed people; although, they have completely normal tissue functions (Watson et al., 2015).

In contrast, in group II, the initial levels of ACHE enzyme, showed statistically significant differences among the three subgroups $(\mathrm{P}=0.02)$. The discrepancy between results of both groups may be due to differences of the anonymous type of OPCs and baseline variability among general populations.

Regarding the final ACHE enzyme levels, there were statistically significant differences among the three sub-groups in both groups. These findings are in agreement with Lionetto et al. (2013) and Watson et al. (2015) who reported significant relationship between ACHE enzyme inhibition following OP exposure and its implication on health, suggesting that ACHE enzyme is a valid biomarker for OP effect rather than exposure.

As regards BuCHE enzyme, statistically significant associations has been demonstrated between the means of initial and final BuCHE enzymes' levels and POP scale in group I, which confirm its role as a sensitive biomarker for assessment of enzyme inhibition and recovery following exposure. This finding confirms the results of Chaudhary et al. (2013), they stated that BuCHE enzyme's levels usually decline to less than $50 \%$ before symptoms are seen, where reduction to $20-50 \%$ is usually associated with mild poisoning, reduction to $10-20 \%$ associated with moderate poisoning and less than $10 \%$ in severe poisoning. Several studies have shown similar findings of the significant correlations between BuCHE enzymes' levels and severity of poisoning (Makwava et al., 2012; Hundekari et al., 2013 and Khan et al., 2016).

In contrast, in group II, there were no statistically significant associations between the mean BuCHE levels (initial and final) and POP scoring. These findings go in accordance with Hassan and Madboly (2013) who found that, inhibition of BuCHE enzyme does not provide confirmatory indicators to clinical severity of poisoning. As many OP insecticides are known to be more potent inhibitors of BuCHE enzyme, however, they don't show such potency regarding ACHE enzyme's inhibition, the enzyme, which is actually responsible for clinical features of OP toxicity. The discrepancy between results of group I and group II can be explained by non specificity of BuCHE enzyme for OP exposure. Records demonstrated that this enzyme may be suppressed in many other pathological conditions other than OP poisoning, unlike ACHE enzyme which is less to be affected by factors other than OPs (Darwish et al. 2016).

Statistically significant differences were found between group I and group II regarding the initial levels of ACHE and BuCHE enzymes. These differences can be explained by disturbances that may occur during sample transportation from Damietta to Mansoura laboratory. Furthermore, the difference in geographic distribution of the patients, personal variations regarding cholinesterase enzymes' levels, concomitant conditions that may affect the enzymes' levels and non-cholinesterase OP effects (Worek and Thiermann, 2013).

The POP scale was compared between the two studied groups. As regard ACHE enzyme activity and BuCHE levels, no statistically 
significant differences were found except, the mean values of initial ACHE enzymes' levels in mild and severe sub-groups that mainly reflect personal variations and the difference between types of ingested OPCs; and those among severe cases between both groups regarding the final levels of BuCHE enzyme. The present work shows reactivation of cholinesterase activity after obidoxime therapy, however, no statistically significant differences between both groups regarding the final levels of ACHE and BuCHE enzymes, was observed, which suggests that no addeffect of obidoxime therapy among patients in group I regarding reactivation of ACHE and BuCHE enzymes.

The results of present study are not consistent with other studies in which oxime therapy caused significant reactivation in cholinesterase enzyme's activity. Thiermann et al. (2010) studied the effect of obidoxime therapy among patients poisoned with parathion; they found prompt response with noticeable increase ACHE enzyme's activity levels.

In both studied groups, there were statistically significant associations between POP scale and the atropine requirement, the need for ventilatory support, duration of hospital stay and clinical outcomes. Similar findings were declared in a previous study by Makwava et al. (2012) which revealed a strong association between the severity of the POP scale and the mean requirements of atropine, total duration of hospital stay, need for ventilatory support and mortalities.

Interestingly, when both groups are compared as regard clinical outcomes, there were statistically significant differences between group I and group II. These results are in accordance with Tang et al. (2013) and Husain (2014) who reported that, combination of atropine and obidoxime is more effective than either drug alone in improving the outcome and reducing both morbidities and mortalities following OP poisoning.

As regard IMS, results of the current study showed that, obidoxime therapy was statistically ineffective regarding prevention of IMS development among OP intoxicated patients. these results are in agreement with Khosya et al. (2013) and Malkarnekar et al. (2014) who reported that administration of obidoxime at recommended doses by $\mathrm{WHO}$ and within short period of ingestion of OP insecticides did not prevent the onset of IMS.

However, Thiermann et al. (2010) and Abedin et al. (2012) who studied the effect of the clinically used oximes (obidoxime and pralidoxime) in prevention of IMS, strongly supported the administration of appropriately dosed obidoxime, in OP poisoned patients. The discrepancy between these studies can be explained by difference in type and dose of oxime therapy, routes of exposure, chemical structure of the OPCs, mixed OP preparations, time of therapy and possibly efforts to decrease absorption or enhance elimination of OPs.

In the present work, clinical and laboratory effects of obidoxime in treatment of OP poisoning, were assessed. The results were contradictory, although no statistically significant differences were found regarding cholinesterase enzymes' reactivation, there were statistically significant differences among both groups regarding the clinical outcome. These findings can be explained by: first, it is difficult to know, how closely ACHE enzyme's inhibition in erythrocytes reflects cholinergic ACHE enzyme in the nervous system since access to blood is easier than access to brain. Thus, the inhibition of ACHE enzyme in erythrocytes may be overestimated relative to that in brain. In addition, ACHE enzyme in brain is restored by de-novo synthesis more rapidly than in erythrocytes where ACHE enzyme's activity is recovered via erythropoiesis (Jokanović, 2012). 
Second, these results may be correlated to the non-reactivating effects of obidoxime. They may exert effects by interactions with the synthesis, release and reuptake of of ACh. Additionally, obidoxime has an antagonistic effect on both muscarinic and nicotinic receptors; it preferentially inhibits muscarinic M2 receptors (Soukup et al., 2013). Since overstimulation of nicotinic receptors is considered to be the cause of death in the OP poisoning, clear anti-nicotinic action of obidoxime is of advantage in this matter (Killi et al., 2014).

\section{Conclusion}

It is concluded that measurement of BuCHE enzymes' levels can be considered a sensitive biomarker for OP exposure and severity, meanwhile, measurement of ACHE activity can be a helpful measure for recovery.

\section{References}

Abedin, M. J.; Sayeed, A. A.; Basher, A.; et al. (2012): "Open-label randomized clinical trial of atropine bolus injection versus incremental boluses plus infusion for organophosphate poisoning in Bangladesh". Journal of Medical Toxicology, 8(2):108-117.

Alfonso, L. F.; Germán, G. V.; Del Carmen, P. C. M. and Hossein, G. (2017): "Adsorption of organophosphorus pesticides in tropical soils: the case of karst landscape of northwestern Yucatan". Chemosphere, 166: 292-299.

Chaudhary, S. C.; Singh, K.; Sawlani, K. K.; et al. (2013): "Prognostic significance of estimation of pseudo- cholinesterase activity and role of pralidoxime therapy in organophosphorous poisoning". Toxicology International, 20 (3):214-217.

Darwish, R. T.; Megahed, H. M.; Ayad, M. W. and Barakat, A. A. A. (2016): "Study of acyl-peptide hydrolase as a probable marker of severity in cases of acute poisoning by cholinesterase enzyme inhibitor insecticides". Tanta Medical Journal, 44(1):4-11.

Eddleston, M. (2018): "Are oximes still indicated for acute organophosphorus insecticide self-poisoning?". Journal of Medical Toxicology, doi.org/10.1007/s13181-018-0651-y.

Eddleston, M. and Chowdhury, F. R. (2016): "Pharmacological treatment of organophosphorus insecticide poisoning: the old and the (possible) new". British Journal of Clinical Pharmacology, 81(3):462-470.

Eddleston, M.; Eyer, P.; Worek, F.; et al. (2008): "Predicting outcome using butyrylcholinesterase activity in organophosphorus pesticide selfpoisoning". QJM: An International Journal of Medicine, 101(6):467-474.

Eddleston, M.; Street, J. M.; Self, I.; et al. (2012): "A role for solvents in the toxicity of agricultural organophosphorus pesticides". Toxicology, 294(2-3): 94103.

Hassan, N. A. and Madboly, A. G. (2013): "Correlation between serum creatine phosphokinase and severity of acute organophosphorus poisoning: A prospective clinical study (20122013)". IOSR Journal of Environmental Science, Toxicology and Food Technology, 4:18-29. 
Hundekari, I. A.; Suryakar, A. N. and Rathi, D. B. (2013): "Acute organophosphorus pesticide poisoning in North Karnataka, India: oxidative damage, haemoglobin level and total leukocyte". African Health Sciences, 13(1):129-136.

Husain, K. (2014): "Delayed neurotoxicity of organophosphorus compounds". Journal of Environmental Immunology and Toxicology, 1:14-21.

Jokanović, M (2012): Neurotoxic disorders and medical management of patients poisoned with organophosphorus and carbamate. In: The Impact of Pesticides. Jokanović, M (Ed.), AcademyPublish.org, USA, P.P. 3962.

Jońca, J.; Żuk, M.; Wasąg, B.; et al. (2015): "New insights into butyrylcholinesterase activity assay: serum dilution factor as a crucial parameter". PloS One, 10(10): e0139480.

Khan, N. U.; Patel, M. J.; Hifath, M. N. M.; et al. (2012): "Prolonged intermediate syndrome due to organophosphate poisoning".

doi: 10.4172/scientificreports. 229.

Khan, S.; Kumar, S.; Agrawal, S. and Bawankule, S. (2016): "Correlation of serum cholinesterase and serum creatine phosphokinase enzymes with the severity and outcome of acute organophosphorus poisoning: study in rural central India". World Journal of Pharmacy and Pharmaceutical Sciences, 5 (4): 1365-1373.

Khosya, S.; Gothwal, S. K.; Banga, V. and Meena, R. (2013): "Malathion poisoning presented as intermediate syndrome and organophosphate induced delayed polyneuropathy in succession: a case report". Journal of Clinical Case Reports, 3(274). doi: $10.4172 / 2165-7920.1000274$
Killi, U. K.; Wsol, V.; Soukup, O.; et al. (2014): "In vitro functional interactions of acetylcholine esterase inhibitors and muscarinic receptor antagonists in the urinary bladder of the rat". Clinical and Experimental Pharmacology and Physiology, 41(2):139-146.

Kumar, G. C.; Bhuvana, K.; Venkatarathnamma, P. N. and Sarala, N. (2015): "Serum creatine phosphokinase as predictor of intermediate syndrome in organophosphorus poisoning". Indian Journal of Critical Care Medicine, 19(7):384-387.

Lionetto, M. G.; Caricato, R.; Calisi, A.; et al. (2013): "Acetylcholinesterase as a biomarker in environmental and occupational medicine: new insights and future perspectives". Biomedical Research International, doi.org/10.1155/2013/321213.

Makwava, P. V.; Odedara, R. V. and Shah, H. D. (2012): "Acute organophosphorus poisoning and clinical admission score association among patients admitted in emergency ward of a tertiary teaching hospital of medical college". Journal of Pharmaceutical and Biomedical Sciences, 17(8):1-5.

Malkarnekar, S.; Naveen, L. and Adam, S. R. (2014): "Organophosphate toxicity presenting with cholinergic crisis, intermediate syndrome and delayed polyneuropathy in succession: a rare presentation". International Journal of Medical Toxicology and Forensic Medicine, 4(4):145-153.

Osman, K. A. (2011): Pesticides and human health. In: Pesticides in The Modern World - Effects of Pesticides Exposure. Stoytcheva, M. (Ed.), InTech, Croatia, P.P. 205-230. 
Roberts, D. M. and Brett, J. (2014): Clinical management of acute OP pesticide poisoning. In: Basic and Clinical Toxicology of Organophosphorus Compounds. Balali-Mood, M. and Abdollahi, M. (Eds.), Springer-Verlag, London, P.P. 141-175.

Sarkar, S.; Nandi, M.; Mondal, R. and Mandal, S. K. (2014): "Organo phosphorus-induced extrapyramidal intermediate syndrome in an adolescent suicide attempt survivor". Journal of Neurosciences in Rural Practice, 5(3):276-278.

Soukup, O.; Jun, D.; Tobin, G. and Kuca, K. (2013): "The summary on nonreactivation cholinergic properties of oxime reactivators: the interaction with muscarinic and nicotinic receptors". Archives of Toxicology, 87(4):711719.

Tang, X.; Wang, R.; Xie, H.; et al. (2013): "Repeated pulse intramuscular injection of pralidoxime chloride in severe acute organophosphorus pesticide poisoning". The American Journal of Emergency Medicine, 31(6):946-949.

Tawa, N.; Rhoda, A. and Diener, I. (2017): "Accuracy of clinical neurological examination in diagnosing lumbosacral radiculopathy: a systematic literature review". BMC musculoskeletal disorders, 18(1):93. doi: 10.1186/s12891-016-1383-2.

Thiermann, H.; Eyer, P. and Worek, F. (2010): "Muscle force and acetylcholinesterase activity in mouse hemidiaphragms exposed to paraoxon and treated by oximes in vitro". Toxicology, 272(1):46-51.

Thiermann, H.; Eyer, P. and Worek, F. (2010): "Muscle force and acetylcholinesterase activity in mouse hemidiaphragms exposed to paraoxon and treated by oximes in vitro". Toxicology, 272(1):46-51.

Watson, A.; Opresko, D.; Young, R. A.; et al. (2015): Organophosphate nerve agents . In: Handbook of Toxicology of Chemical Warfare Agents, $2^{\text {nd }}$ edition. Gupta, R.C. (Ed), Elsevier Inc, USA, P.P. 87-110.

Worek, F. and Thiermann, H. (2013): "The value of novel oximes for treatment of poisoning by organophosphorus compounds". Pharmacology and Therapeutics, 139(2):249-259.

Worek, F.; Eyer, P. and Thiermann, H. (2012): "Determination of acetylcholinesterase activity by the ellman assay: a versatile tool for in vitro research on medical countermeasures against organophosphate poisoning". Drug Testing and Analysis, 4(3-4):282-291.

World Health Organization (WHO) (2014): Initial clinical management of patients exposed to chemical weapons. 


\title{
تأثير علاج الأبيدوكسيم على إعادة تنشيط إنزيمات الكولين استزيز في المرضى الذين

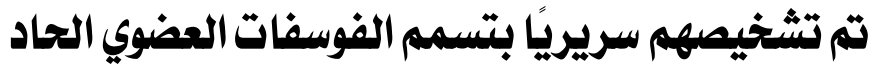

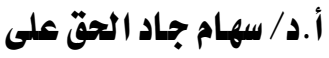 \\ د د علياء أبـا الحسن عثمان
}

أ.د أ عبد العزيز أبو الفتوح غانم

أ.م.د/ أهند محمود أبو العطا

قسم الطب الثرعي والسموم الإكلينيكية ـ كلية الطب - جامعة المنصورة

إن التسمم بالفوسفات العضوي له أهمية سريريه كبيرة،لاسيما في البلدان الناميـة، بسبب عو اقبه الصحية الكبرى. وقد أجريت هذه الدر اسة لتقييم دور الأوبيدوكسيم في تنشيط إنزيمات الكولين إستريز (الأستيل كولين

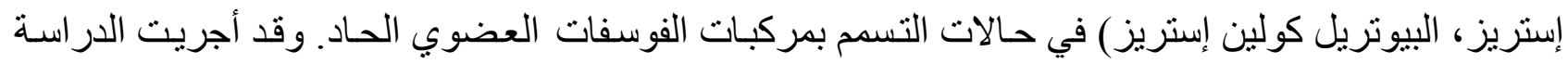
على مجمو عتين.المجمو عة الأولى: • 0 مريض تم علاجهم بالأوبيدوكسيم بعد التسمم الحساد لمركبات الفوسفات

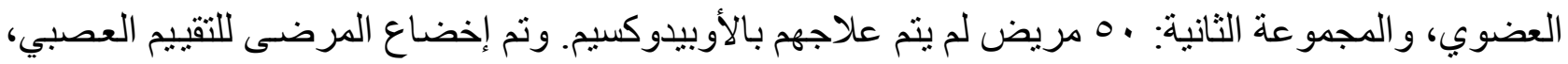

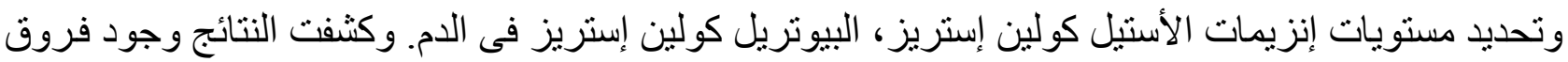

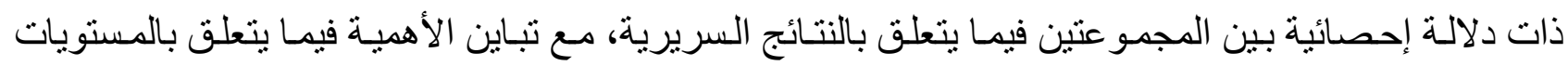

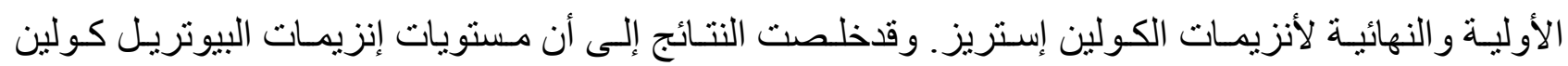

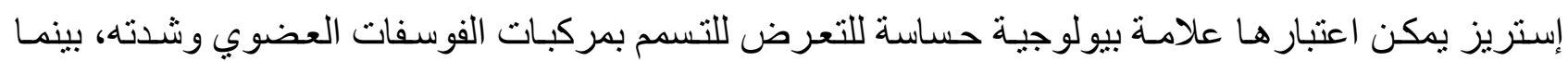
يعكس نشاط الأستيل كولين إستريز درجة التعافي. 